\section{Arbuscular Mycorrhizal Inoculant Increases Yield of Spice Pepper and Affects the Indigenous Fungal Community in the Field}

\author{
Ildikó Hernádi and Zita Sasvári \\ Microbiology and Environmental Toxicology Group, Plant Protection Institute, \\ Szent István University, 2100 Gödöllö, Hungary
}

\begin{abstract}
Jana Albrechtová
Department of Experimental Plant Biology, Faculty of Science, Charles University in Prague, 12844 Czech Republic; and Institute of Botany of the Academy of Sciences of the Czech Republic, Pruhonice, 25243 Czech Republic
\end{abstract}

\author{
Miroslav Vosátka \\ Institute of Botany of the Academy of Sciences of the Czech Republic, \\ Pruhonice, 25243 Czech Republic; and Symbiom Ltd., Sazava 170, Lanskroun, \\ 56301 Czech Republic
}

\section{Katalin Posta ${ }^{1}$ \\ Microbiology and Environmental Toxicology Group, Plant Protection Institute, Szent István University, 2100 Gödöllö, Hungary}

Additional index words. Glomus sp. mycorrhizal products, PCR-RFLP, pepper

\begin{abstract}
Although the majority of horticultural crops are mycorrhiza-dependent, the role of arbuscular mycorrhizal (AM) inoculation in plant production has been neglected in high-input agriculture. Field application of a commercial inoculum mix of Glomus spp. was tested in spice pepper (Capsicum annuum L. var. longum), cv. Szegedi, cultivation. With polymerase chain reaction-restriction fragment length polymorphism (PCRRFLP), differences in small subunit ribosomal RNA genes were used to characterize groups of arbuscular mycorrhizal fungi (AMF) with respect to effects of mycorrhizal inoculation on an indigenous AMF population. The AMF inoculant was able to establish in the rhizosphere of pepper plants and mycorrhizal inoculation increased yield of spice pepper by more than $65 \%$ compared with the non-treated control plants. Having relatively high root colonization in the control, non-inoculated treatment indicated high presence of indigenous populations of AMF in the field soil. Although the inoculation affected structure of the resident AM fungal community, it did not influence the composition of AMF associated with pepper roots significantly.
\end{abstract}

Sweet pepper (Capsicum annuum L.) is an important vegetable containing bioactive metabolites with potential health-promoting properties having antioxidant activity (Marín et al., 2004), carotenoids, capsaicinoids, capsinoids, flavonoid glycosides, tocopherols, and ascorbic acid (Khoo et al., 2011; Márkus et al., 1999). In addition, they contain serotonin

\footnotetext{
Received for publication 2 Nov. 2011. Accepted for publication 14 Mar. 2012.

Research supported by the TÁMOP-4.2.2.B-10/1 "Development of a complex educational assistance/ support system for talented students and prospective researchers at the Szent István University" project and by Eurostars Project Microfruit E!4366.

We thank Franco Magurno for help and comments on this article and Aleš Látr from Symbiom, Ltd., for collaboration within the Microfruit project.

${ }^{1}$ To whom reprint requests should be addressed; e-mail posta.katalin@mkk.szie.hu.
}

derivatives (Kang et al., 2009). Until the introduction of the first sweet pepper in the 1920 s, Hungary was best known for hot paprika-spice pepper (Capsicum annuum L. var. longum), which is protected by the European Union as a national cultivar. It is traditionally cultivated in the Szeged and Kalocsa regions of Hungary (Somogyi et al., 1500 ha (average 2000-2009). A growing awareness of sustainable agriculture, highquality food, and more information on how food is produced has caused a demand for reduced chemical inputs in pepper cultivation.

Mycorrhiza can function in horticulture as a sustainable, biocontrol agent against pathogens, a bioprotectant against toxic stresses, and as a soil-improving antierosion agent (Vosátka and Albrechtová, 2008). The interest in use of mycorrhiza in horticulture is mostly the result of the ability of AM fungi to enhance uptake of phosphorus $(\mathrm{P})$ and water, 2000 ) and $\approx 28.6 \mathrm{t}$ is annually produced from decrease agrochemical inputs during production, and increase resistance to biotic and abiotic stresses (Wu and Zou, 2010; Wu et al., 2011). There are other important aspects from use of mycorrhiza including improved seedling survival, increased growth and yield, uniformity of horticultural crops, and earlier and increased flowering (Azcon-Aguilar and Barea, 1997; Vosátka and Albrechtová, 2008). The improvement of vegetable nutritional quality can be the result of existence of mycorrhizal symbiosis through activation of antioxidant, phenylpropanoid, or carotenoid pathways (Baslam et al., 2011).

Generally, pepper belongs to mycorrhizadependent vegetables and mycorrhiza have been shown to significantly improve pepper fruit yield (Douds and Reider, 2003; Gaur et al., 1998; Kaya et al., 2009; Russo and Perkins-Veazie, 2010), to enhance seedling quality and to compensate for $\mathrm{P}$ and zinc ( $\mathrm{Zn})$ deficiency in P- and Zn-deficient soils (Ortas et al., 2011). Contents of bioactive compounds in spice red pepper can be changed depending on weather conditions during vegetative growth (Márkus et al., 1999) and postharvest storage or after-ripening (Somogyi et al., 2000). The AMF was found to be active as a protective agent against Phytophthora capsici (Zheng et al., 2005) or Verticillium spp. (Goicoechea et al., 2010), pathogens infecting pepper.

There are only a few studies on effects of commercial mycorrhizal inoculants on growth and development of horticultural plants (Cwala et al., 2010; Gaur et al., 1998) and to study their influence on indigenous mycorrhiza population (Antunes et al., 2009; Mummey et al., 2009).

The aim of the present work was to determine effects of the commercially available AM inoculant Symbivit, a mixture of six species of Glomus spp., on growth and yield of field-grown spice pepper and to determine if any change in the soil community of rootcolonizing AM fungi occurs as a consequence of artificial inoculation.

\section{Materials and Methods}

Experimental design. The experiment was carried out at the Experimental Station of the Plant Protection Institute, Szent István University Gödöllo”, Hungary (long. 19²1'39.85", lat. $47^{\circ} 35^{\prime} 37^{\prime} 63^{\prime \prime}$ ) in 2009 . The climate of the region is continental with a mean annual temperature and precipitation of $10.6^{\circ} \mathrm{C}$ and $539 \mathrm{~mm}$, respectively. Seedlings of pepper (Capsicum annuum L. var. longum), cv. Szegedi, were propagated at the beginning of April in a greenhouse using special horticulture substrate [Klasmann TS3: $80 \%$ white sphagnum peat and $20 \%$ frozen black sphagnum peat, slow-release $14 \mathrm{~N}-16 \mathrm{P}-18 \mathrm{~K}(\mathrm{w} / \mathrm{w} / \mathrm{w})$ fertilizer, $\mathrm{pH}$ 6.00] for 7 weeks and were bedded out on 26 May in a sandy soil with low P supply. The major soil properties in the 0 - to 20-cm layer were: $\mathrm{pH}(\mathrm{KCl})$ : 6.67 ; humus content: 1.56 ; salt: $0.05 \%, \mathrm{AL}-\mathrm{P}_{2} \mathrm{O}_{5}$ : $84.0 \mathrm{mg} \cdot \mathrm{kg}^{-1}$; $\mathrm{AL}-\mathrm{K}_{2} \mathrm{O}: 113.0 \mathrm{mg} \cdot \mathrm{kg}^{-1}$; ALCa: $1347.0 \mathrm{mg} \cdot \mathrm{kg}^{-1}$, AL-Mg $142.0 \mathrm{mg} \cdot \mathrm{kg}^{-1}$, 
$\mathrm{NH}_{4}{ }^{+}-\mathrm{N}: 0.59 \mathrm{mg} / 100 \mathrm{~g}, \mathrm{NO}_{3}{ }^{-} \mathrm{N}: 2.19 \mathrm{mg} /$ $100 \mathrm{~g}$ copper: $3.63 \mathrm{mg} \cdot \mathrm{kg}^{-1}$, iron 1016.0 $\mathrm{mg} \cdot \mathrm{kg}^{-1}$, manganese $263.0 \mathrm{mg} \cdot \mathrm{kg}^{-1}, \mathrm{Zn} 6.49$ $\mathrm{mg} \cdot \mathrm{kg}^{-1}$. Phosphorus, potassium, and nitrogen concentrations were determined according to Egner et al. (1960) using ammonium lactateacetic acid and $\mathrm{CaCl}_{2}$ extraction, respectively. Metal contents of the soil were assessed after digestion with concentration of $\mathrm{HNO}_{3}$ and the extracts were analyzed with plasma emission spectrometry using a Jobin-Yvon JY24 ICP instrument (Longjumeau, France).

A variety of cereals have been grown alternatively on the site; however, the last 2 years were covered by grass/cover to restore soil fertility. A moldboard plough to $25 \mathrm{~cm}$ depth was used for soil tillage after each harvesting time and conventional seedbeds were prepared by chisel plowing followed by disking.

Before transplanting, mycorrhizal fungi in a commercial product Symbivit ${ }^{\circledR}$ (mixture of G. intraradices BEG140, G. mosseae BEG95, G. etunicatum BEG92, G. claroideum BEG96, G. microaggregatum BEG56, G. geosporum BEG199, without bioadditives) produced by Symbiom Ltd. (Lanskroun, Czech Republic; http://www.symbiom.cz) was applied at $15 \mathrm{~g}$ of inoculum (consisting of 400 propagules $/ g$ ) per pepper seedling into the planting hole and seedlings were planted immediately. In the experiment, 50 plants inoculated with Symbivit (AM-treated) and 50 non-inoculated plants (control) were set up in three replicates using a randomized complete block design. Five randomly chosen plants from each treatment were destructively harvested at the end of the experiment (on 3 Sept.); shoots and roots were dried at $60{ }^{\circ} \mathrm{C}$ for $72 \mathrm{~h}$ and separately weighed. Harvesting was by hand twice and cumulative weight of yield from 100 plants per treatment evaluated.

Assessment of mycorrhizal colonization. Samples for estimating root colonization were collected on 26 June, 27 July, 14 Aug., and 3 Sept. At each time, three randomly chosen from three repetitive plots of the same treatment plants were dug out with a soil core of $25 \times 25 \times 25 \mathrm{~cm}$. The total number of plant samples was 36 from both treatments for a total of 72 plants. The roots and the soil were stored in separate plastic bags at $4{ }^{\circ} \mathrm{C}$ until processing within $24 \mathrm{~h}$. Approximately half of the root systems, at least $500 \mathrm{mg}$ of fine roots, from each plant was transferred to separate tubes and was subjected to Trypan blue staining (Phillips and Hayman, 1970). Internal fungal structures (hypae, arbuscules, vesicules) were examined under a stereomicroscope at $\times 100$ magnification and the percentage of root length colonized calculated using the gridline intersect method (Giovanetti and Mosse, 1980).

Molecular analysis. Five randomly sampled root segments (2-4 cm long) of each of the 18 plants collected in June and August (first and third sampling times) and $2 \mathrm{~g}$ of Symbivit inoculant were separately subjected to DNA extraction using the DNeasy ${ }^{\circledR}$ plant Mini Kit (Quiagen, Chatsworth, CA) following the manufacturer's instructions. Fragments of 18S rDNA gene sequences were amplified using the primer pairs AMV4.5F (5'-AAT TGG AGG GCA AGT CTG G-3' ${ }^{\prime}$-AMV4.5R (5'-AGC AGG TTA AGG TCT CGT TCG T$\left.3^{\prime}\right)$ and AMV4.5NF (5'-AAG CTC GTA GTT GAA TTT CG-3')-AMV4.5NR (5'-CAC CCA TAG AAT CAA GAA AGA- $3^{\prime}$ ) in the first and second nested PCR according to Saito et al. (2004). The PCR mixtures $(20 \mu \mathrm{L})$ contained $2 \mu \mathrm{L}$ of $10 \times$ PCR buffer (Fermentas, Vilnius, Lithuania), $1.5 \mu \mathrm{L}$ of $25 \mathrm{~mm} \mathrm{MgCl}_{2}$, $2 \mu \mathrm{L}$ of dNTP mix, $1.0 \mu \mathrm{L}$ of each primer (40 $\mathrm{mm}), 1 \mu \mathrm{L}$ of template DNA, $0.2 \mu \mathrm{L}(5 \mathrm{U})$ of Taq polymerase (Fermentas), and $11.3 \mu \mathrm{L}$ of milliQ water. For amplification, the following program was used: initial denaturation at $95{ }^{\circ} \mathrm{C}$ for $10 \mathrm{~min}$, followed by 20 (first PCR) and 40 cycles (second PCR) consisting of $30 \mathrm{~s}$ at $94{ }^{\circ} \mathrm{C}, 30 \mathrm{~s}$ at $60{ }^{\circ} \mathrm{C}$, and $1 \mathrm{~min}$ at $72{ }^{\circ} \mathrm{C}$ and a final extension of $72{ }^{\circ} \mathrm{C}$ for $10 \mathrm{~min}$. Amplification products were separated by electrophoresis in $2 \%(\mathrm{w} / \mathrm{v})$ agarose gels and stained with ethidium bromide. The PCR products were purified by isolating fragments of appropriate size $(\approx 650 \mathrm{bp})$ using the GFX PCR DNA and Gel Band Purification Kit (GE Healthcare, Amersham Biosciences, Amersham, UK). PCR products amplified from samples, collected at the same time, and from the same treatment were pooled as recommended by Renker et al. (2006). These pools and PCR product from inoculant were cloned separately into pGEM $^{\circledR}$-T Easy vector (3015 bp) using the pGEM $^{\circledR}-\mathrm{T}$ Easy Vector System (Promega, Madison, WI) and transformed into Escherichia coli $\mathrm{DH} 5 \alpha$. Plasmids purified from positive clones using the Wizard ${ }^{\circledR}$ Plus SV Minipreps DNA Purification System Kit (Promega) were digested independently with BSuR1 (Fermentas) to identify RFLP classes. We used the detected RFLP types to indicate AM fungal ribotype reachness. After cloned sequence characterization, the relative occurrence of sequences representing RFLP types in the root subsamples was calculated.

Statistical analyses. Treatment effects on measured variables were tested for normality and subjected to analysis of variance and comparisons between means carried out using Tukey's honestly significant difference test at $P<0.05$. Data were analyzed using Statistica 6.1 (StatSoft, Tulsa, OK) software.

\section{Results}

According to the Tukey test, mycorrhizal inoculation moderately but significantly increased fresh $(P=0.015)$ and highly significantly enhanced dry weights $(P=0.00051)$ of shoots of spice pepper; there was no significant difference in the root weight as a result of treatment (Table 1). Treated plants exhibited an increase in cumulative crop production compared with controls.

At each sampling date, except for that in July, the percent of mycorrhizal root colonization was greater for the AM-treated than control plants (Table 1). The lowest degree of colonization was observed in June in the control treatment. However, there was a relative high indigenous AMF population.
Colonization percent increased during vegetative development and there was a slight decrease at harvest.

Root colonization in AM-treated plants tended to be more uniform throughout the growth period than for control plants.

Samples collected in August were used to assess AMF diversity because both treatments exhibited the highest level of colonization at this time. The mycorrhizal-specific primer pair of Saito et al. (2004) amplified PCR products with the expected sizes of $\approx 650$ $\mathrm{bp}$, which, after being digested by restriction enzyme and run on agarose gel, produced different RFLP profiles of the AMF community (Fig. 1).

Approximately 10 different AMF genotypes of both treatments, including six overlapping, altogether 14, could be observed at the first sampling date (Fig. 1A). Different genotypes but the same number of groups were found (Groups of 4, 6, 9, 10) in controls and Groups of 8, 12, 13, and 14 in AM-treated plants. More than $85 \%$ and $70 \%$ of observed AMF clones belonged to Groups 1, 2, and 7 and RFLP Groups 1, 2, 3, and 5 in AMtreated and control plants, respectively.

Ten RFLP types of AM fungi clones were observed in August and only three (Groups 1, 5 , and 9) reached the level of $10 \%$ frequency (Fig. 1B). Ribotypes not found in the earlier sample included Groups 15, 16, 17, 18, and 19 and a number of groups found in June were absent in August (Groups 2, 3, 4, 6, 7, 8, 12,13 , and 14). There were five overlapping Groups $(1,5,9,10$, and 18) of mycorrhizal fungal clones between treatments in August plus three genotypes (Groups 11, 15, and 19) were observed in controls and Groups 16 and 17 in AM-treated plants at low-frequency levels.

Only two ribotypes, belonging to Groups 1 and 5, were observed in the RFLP profile of the AMF community in Symbivit inoculant.

\section{Discussion}

Inoculation with a commercial product Symbivit, containing a mixture of nonindigenous Glomus spp., promoted plant growth and yield benefits of spice pepper, $\mathrm{cv}$. Szegedi. The increase in pepper yield as a consequence of inoculation was also observed by others (Douds and Reider, 2003; Gaur et al., 1998; Kaya et al., 2009; Russo and Perkins-Veazie, 2010). Despite the ecological consequences of these economic benefits, namely, how resident communities respond to AMF inoculation is still unknown.

Responses of plants to AM inoculation depended on soil characteristics (George, 2000), native mycorrhizal populations (Requena et al., 2001), functional differences among isolates (Pellegrino et al., 2011), and quantity of inoculants and host plants (Antunes et al., 2009). Furthermore, mycorrhizal function can range from mutualistic to parasitic with host plants (Johnson et al., 1997; Jones and Smith 2004; Klironomos 2003). Most studies estimate responses to single AM fungal strain (Antunes et al., 2009; Koch et al., 2011), 
whereas only few reports showed the effects of mixed inoculant, represented by exotic species (Lekberg et al., 2007). Our results represent a step forward toward understanding the use of a mix of inoculants.

The results of our field study showed that adding inoculant to soil containing nonresident AM fungi increased not only yield of spice pepper, but affected the fungal community without necessarily changing the structure of resident AMF. Analyzing the AMF ribotypes profile of Symbivit inoculant showed that only ribotypes 1 and 5 presented in the commercial inoculums but were detected both in roots of control and inoculated plants. The inoculation affected structure of the resident AM fungal community, intended as relative abundance of some ribotypes, but

Table 1. Effects of a arbuscular mycorrhizal Glomus mixture (Symbivit commercial product) treatment on growth, cumulative crop production, and root colonization during cultivation of spice pepper in the season 2009.

\begin{tabular}{|c|c|c|c|c|c|c|c|c|c|}
\hline \multirow[b]{2}{*}{ Treatments } & \multicolumn{2}{|c|}{$\begin{array}{l}\text { Fresh wt } \\
\text { (g/plant) }\end{array}$} & \multicolumn{2}{|c|}{$\begin{array}{c}\text { Dry wt } \\
\text { (g/plant) }\end{array}$} & \multicolumn{4}{|c|}{ Colonization $(\%)^{z}$} & \multirow{2}{*}{$\begin{array}{c}\text { Cumulative crop } \\
\text { production } \\
\text { (g/100 plants) }\end{array}$} \\
\hline & Root & Shoot & Root & Shoot & 26 June & 27 July & 14 Aug. & 3 Sept. & \\
\hline AM-treated & $1.66 \mathrm{a}^{\mathrm{y}}$ & $19.32 \mathrm{~b}$ & $1.30 \mathrm{a}$ & $13.45 \mathrm{~b}$ & $60 \pm 5$ & $64 \pm 9$ & $79 \pm 5$ & $76 \pm 4$ & 5251.27 \\
\hline Control & $1.77 \mathrm{a}$ & $13.22 \mathrm{a}$ & $0.97 \mathrm{a}$ & $7.09 \mathrm{a}$ & $38 \pm 4$ & $59 \pm 5$ & $70 \pm 3$ & $58 \pm 6$ & 3189.56 \\
\hline
\end{tabular}

${ }^{2}$ Root colonization measured at four different times.

${ }^{y}$ Values in a column followed by the same letter are not significantly different, $P \leq 0.05$, Tukey test; values mean of five observations. did not influence the composition significantly. In fact, the dominant ribotypes 1, 5, and 9 were found in August at both treatments, indicating that there were no really term period as found by Schwartz et al. (2006). However, as a result of limitations of the applied technique, we could not draw conclusions about the change at the species level but only at the ribotype level. In addition, AM fungi occurring at low frequency cannot have been detected. Our findings are in accordance with the results of Antunes et al. (2009) who inoculated maize roots with a commercial product containing non-indigenous $G$. intraradices. In contrast, Koch et al. (2011) found that the inoculation with two strains of $G$. intraradices decreased the ribotype richness aggressive AMF isolates during that short- of the native AM fungal community in roots as well as Mummey et al. (2009) using preinoculation of plants with a mix of AMF species.

The effect of seasonality, as a change in the fungal community colonizing the roots of pepper, was also detected using molecular tools. Analyses of seasonality of AM fungi have been carried out in few studies and mostly based on spore counting (Gemma and Koske, 1988; Sasvári et al., 2011). A decreased number of AMF phylotypes was detected both in control and inoculated treatments in August compared with the mycorrhizal population measured in June suggesting a dominant effect of only one or some isolates of the complex AM fungal community. This fluctuation throughout the season could be the result of changes both in the abiotic (nutrient ability) and biotic (root exudation, microbiological interaction) environment (Cheng, 2008; Husband et al., 2002).

Mycorrhizal technology is being used more frequently in horticultural vegetable production (Vosátka and Albrechtová, 2008) and an international mycorrhizal industry is developing (Vosátka et al., 2008). Under the threat of depletion of world phosphate deposits, use of mycorrhizal inoculation in horticulture becomes even more desirable as a result of savings in chemical inputs and use of renewable

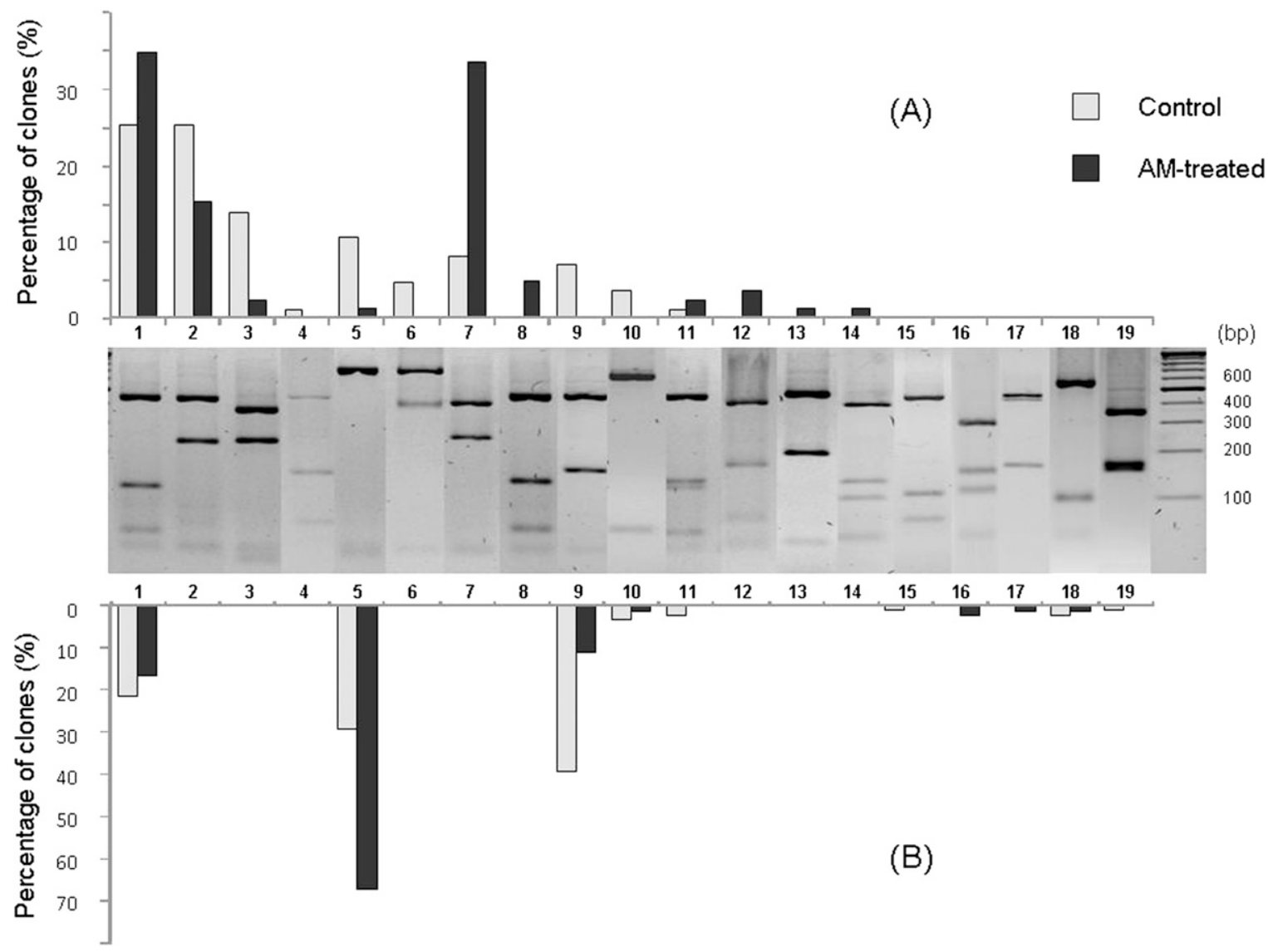

Fig. 1. Percentage distribution of PCR-RFLP profiles of AM fungi recovered from pepper roots collected in June (A) and in August (B) with mycorrhizal-specific primers (AMV4.5NF-AMV4.5NR) after digestion with endonuclease BSuR1 affected by mycorrhizal inoculation. The control was roots from plants without inoculation, AM-treated: roots from plants treated with mycorrhizal inoculant (Symbivit). PCR-RFLP = polymerase chain reaction-restriction fragment length polymorphism; $\mathrm{AM}=$ arbuscular mycorrhizal. 
materials in vegetable production. The AMbased commercial inoculant Symbivit was able to establish in roots of plants and increased yield of spice pepper. Introduction of a mixed Glomus species inoculant of exogenous AMF strains caused a shift in the indigenous AMF community as shown by PCR-RFLP results. However, there was no remarkable decrease in AMF species diversity and apparently no deleterious effects connected with aggressiveness regarding native populations of the AMF. Moreover, our study indicates that $\mathrm{AM}$ fungal introductions can promote plant growth benefits in such situations, not necessarily affecting the structure of resident AM fungal.

Further research is needed to specify the shift in the AMF community and to consider long-term effects of inoculation on maintenance of diversity of the AMF community.

\section{Literature Cited}

Antunes, P.M., A.M. Koch, K.E. Dunfield, M.M. Hart, A. Downing, M.C. Rillig, and J.N. Klironomos. 2009. Influence of commercial inoculation with Glomus intraradices on the structure and functioning of an AM fungal community from an agricultural site. Plant Soil 317:257-266.

Azcon-Aguilar, C. and J.M. Barea. 1997. Applying mycorrhiza biotechnology to horticulture: Significance and potentials. Sci. Hort. 68:1-24.

Baslam, M., I. Garmendia, and N. Goicoechea. 2011. Arbuscular mycorrhizal fungi (AMF) improved growth and nutritional quality of greenhousegrown lettuce. J. Agr. Food Chem. 59:55045515.

Cheng, W. 2008. Rhizosphere priming effect: Its functional relationships with microbial turnover, evapotranspiration, and C-N budgets. Soil Biol. Biochem. 41:1795-1801.

Cwala, Y., C.P. Laubscher, P.A. Ndakidemi, and A.H. Meyer. 2010. Mycorrhizal root colonisation and the subsequent host plant response of soil less grown tomato plants in the presence and absence of the mycorrhizal stimulant. Mycotech. Afr. J. Microbiol. Res. 4:414-419.

Douds, D.D. and C. Reider. 2003. Inoculation with mycorrhizal fungi increases the yield of green peppers in a high P soil. Biol. Agr. Hort. 21:91102.

Egner, H., H. Riehm, and W.R. Mingo. 1960. Untersuchungen über die chemische Bodenanalyse als Grundlage für die Beurteilung des Nährstoffzustandes der Böden. Kungl. Lantbrukshögsk. Ann. Uppsala 26:199-215.

Gaur, A., A. Adholeya, and K.G. Mukerji. 1998. A comparison of AM fungi inoculants using Capsicum and Polianthes in marginal soil amended with organic matter. Mycorrhiza 7: 307-312.

Gemma, J.N. and R.E. Koske. 1988. Seasonal variation in spore abundance and dormancy of Gigaspora gigantea and mycorrhizal inoculum potential of a dune soil. Mycologia 80:211-216.

George, E. 2000. Nurient uptake. Contribution of arbuscular mycorrhizal fungi to plant mineral nutrition, p. 307-343. In: Kapulnik, Y. and D.D.
Douds, Jr. (eds.). Arbuscular mycorrhizas: Physiology and function. Kluwer, Dortrecht, Netherlands.

Giovanetti, M. and B. Mosse. 1980. An evaluation of techniques for measuring vesicular-arbuscular mycorrhizal infection in roots. New Phytol. 84:489-500.

Goicoechea, N., I. Garmendia, M. Sanchez-Diaz, and J. Aguirreolea. 2010. Arbuscular mycorrhizal fungi (AMF) as bioprotector agents against wilt induced by Verticillium spp. in pepper. Span. J. Agr. Res. 8(suppl 1):S25-S42.

Husband, R., E.A. Herre, S.L. Turner, R. Gallery, and J.P.W. Young. 2002. Molecular diversity of arbuscular mycorrhizal fungi and patterns of host association over time ans space in a tropical forest. Mol. Ecol. 11:2669-2678.

Johnson, N.C., J.H. Graham, and F.A. Smith. 1997. Functioning of mycorrhizal associations along the mutualism-parasitism continuum. New Phytol. 135:575-586.

Jones, M.D. and S.E. Smith. 2004. Exploring functional definitions of mycorrhizas: Are mycorrhizas always mutualisms? Can. J. Bot. 82 1089-1109.

Kang, K., S. Park, Y.S. Kim, S. Lee, and K. Back. 2009. Biosynthesis and biotechnological production of serotonin derivatives. Appl. Microbiol. Biotechnol. 83:27-34.

Kaya, C., M. Ashraf, O. Sonmez, S. Aydemir, A.L. Tuna, and M.A. Cullu. 2009. The influence of arbuscular mycorrhizal colonisation on key growth parameters and fruit yield of pepper plants grown at high salinity. Sci. Hort. 121:1-6.

Khoo, H.E., K.N. Prasad, K.W. Kong, Y. Jiang, and A. Ismail. 2011. Carotenoids and their isomers: Color pigments in fruits and vegetables. Molecules 16:1710-1738.

Klironomos, J.N. 2003. Variation in plant response to native and exotic arbuscular mycorrhizal fungi. Ecol. 84:2292-2301.

Koch, A.M., P.M. Antunes, E.K. Barto, D. Cipollini, D.L. Mummey, and J.N. Klironomos. 2011. The effects of arbuscular mycorrhizal (AM) fungal and garlic mustard introductions on native AM fungal diversity. Biol. Invasions 13:1627-1639.

Lekberg, Y., R.T. Koide, J.R. Rohr, L. Aldrichwolfe, and J.B. Morton. 2007. Role of niche restrictions and dispersal in the composition of arbuscular mycorrhizal fungal communities. J. Ecol. 95: 95-105.

Marín, A., F. Ferreres, F.A. Tomas-Barberan, and M.I. Gil. 2004. Characterization and quantitation of antioxidant constituents of sweet pepper (Capsicum annuum L.). J. Agr. Food Chem. 52:3861-3869.

Márkus, F., H.G. Daood, J. Kapitány, and P.A. Biacs. 1999. Change in the carotenoid and antioxidant content of spice red pepper (paprika) as a function of ripening and some technological factors. J. Agr. Food Chem. 47:100-107.

Mummey, D.L., P.M. Antunes, and M.C. Rillig. 2009. Arbuscular mycorrhizal fungi pre-inoculant identity determines community composition in roots. Soil Biol. Biochem. 41:1173-1179.

Ortas, I., N. Sari, C. Akpinar, and H. Yetisir. 2011. Screening mycorrhiza species for plant growth, $\mathrm{P}$ and $\mathrm{Zn}$ uptake in pepper seedling grown under greenhouse conditions. Sci. Hort. 128:9298.
Pellegrino, E., S. Bedini, L. Avio, E. Bonari, and M. Giovannetti. 2011. Field inoculation effectiveness of native and exotic arbuscular mycorrhizal fungi in a Mediterranean agricultural soil. Soil Biol. Biochem. 43:367-376.

Phillips, J.M. and D.S. Hayman. 1970. Improved procedures for clearing roots and staining parasitic and vesicular-arbuscular mycorrhizal fungi for rapid assessment of infection. Trans. Br. Mycol. Soc. 55:158-161.

Renker, C., K. Weißhuhn, H. Kellner, and F. Buscot. 2006. Rationalizing molecular analysis of field-collected roots for assessing diversity of arbuscular mycorrhizal fungi: To pool, or not to pool, that is the question. Mycorrhiza 16: 525-531.

Requena, N., E. Perez-Solis, C. Azcón-Aguilar, P. Jeffries, and J.M. Bareal. 2001. Management of indigenous plant-microbe symbioses aids restoration of desertified ecosystems. Appl. Environ. Microbiol. 67:495-498.

Russo, V.M. and P. Perkins-Veazie. 2010. Yield and nutrient content of bell pepper pods from plants developed from seedlings inoculated, or not, with microorganisms. HortScience 45:352358.

Saito, K., Y. Suyama, S. Sato, and K. Sugawara. 2004. Defoliation effects on the community structure of arbuscular mycorrhizal fungi based on 18S rDNA sequences. Mycorrhiza 14:363373.

Sasvári, Z., L. Hornok, and K. Posta. 2011. The community structure of arbuscular mycorrhizal fungi in roots of maize grown in a 50-year monoculture. Biol. Fertil. Soils 47:167-176.

Schwartz, M.W., J.D. Hoeksema, C.A. Gehring, N.C. Johnson, J.N. Klironomos, L.K. Abott, and A. Pringle. 2006. The promise and the potential consequences of the global transport of mycorrhizal fungal inoculum. Ecol. Lett. 9:501-515

Somogyi, N., M. Pék, and A. Mihály. 2000. Applied spice paprika (Capsicum annuum L. var. longum) growing technologies and processing in Hungary. Acta Hort. 536:389-396.

Vosátka, M. and J. Albrechtová. 2008. Theoretical aspects and practical uses of mycorrhizal technology in floriculture and horticulture, p. 466479. In: Teixeira da Silva, J.A. (ed.). Floriculture, ornamental and plant biotechnology. Advances and topical issues. Glob. Sci. Books Ltd., Takamatsu, Japan.

Vosátka, M., J. Albrechtová, and R. Patten. 2008. The international market development for mycorrhizal technology, p. 419-438. In: Varma, A. (ed.). Mycorrhiza. Springer-Verlag, Berlin, Germany.

Wu, Q.S. and Y.N. Zou. 2010. Beneficial roles of arbuscular mycorrhizas in citrus seedlings at temperature stress. Sci. Hort. 125:289-293.

Wu, Q.S., Y.N. Zou, and X.H. He. 2011. Differences of hyphal and soil phosphatase activities in drought-stressed mycorrhizal trifoliate orange (Poncirus trifoliata) seedlings. Sci. Hort. 129:294-298.

Zheng, H.Z., C.L. Cui, Y.T. Zhang, D. Wang, Y. Jing, and K.Y. Kim. 2005. Active changes of lignifications-related enzymes in pepper response to Glomus intraradices and/or Phytophthora capsici. J. Zhejiang Univ. Sci. B 6:778-786. 